\title{
IMMUNISATION AND THE LAW: SLIPPERY SLOPE TO A HEALTHY SOCIETY
}

\author{
Jessica Kerr*
}

The immunisation of children against communicable diseases is a crucial public health intervention. Yet the understandable prioritisation of parental autonomy within New Zealand immunisation policy has contributed to consistently unsatisfactory coverage rates, in both absolute and comparative terms. If our immunisation law could be strengthened to eliminate 'passive' nonimmunisation without fatally undermining parental choice, the goals of 'population immunity' might be achievable. Of the three reform options explored by this paper, two are rejected as unworkable. The first, a universal mandatory immunisation requirement, might be justifiable in principle but would encounter prohibitive public opposition. The second, an 'informed choice' requirement limited to beneficiaries, is unprincipled and potentially ineffective. The recommended option is more moderate and equitable. Creating a presumption in favour of immunisation at the point of schoolentry would shift the legal focus from 'informed consent' to United States-style 'informed refusal'. The degree of effort required to invoke a statutory exemption to immunisation would depend upon the extent to which policy-makers were satisfied that only parents implacably and legitimately opposed to immunisation were invoking it. Barring a dramatic increase in the size of the antiimmunisation lobby, it is suggested that an informed refusal requirement could successfully eliminate passive non-immunisation, thereby potentially achieving population immunity while substantially preserving parental autonomy.

\section{INTRODUCTION}

Childhood immunisation policy ... contemplates numerous complex, contentious, and controversial themes: a state's interest in protecting public health must be balanced against an individual's medical treatment considerations; concepts of informed consent and personal autonomy must be balanced against state mandates; minor-patients' rights and public interests must be balanced against parental

* Clerk to the Rt Hon Justice Blanchard, Supreme Court of New Zealand. This is an abridged version of a paper submitted as part of the LLB (Hons) programme at Victoria University of Wellington. 
rights; and religious and personal philosophies must be balanced against science and medicine. ... The prospect of harmoniously resolving all of these concerns appears daunting. ${ }^{1}$

The New Zealand government, like others around the world, ranks immunisation as among the most important public health interventions ever developed. ${ }^{2}$ Yet, notwithstanding optimistic policy objectives, New Zealand has consistently failed to secure the immunisation of enough children against targeted diseases to attract the benefits associated with "population immunity". 3

This article addresses the clear opportunity that exists to improve New Zealand's immunisation record. It explores the prospect of drawing on the persuasive and, potentially, coercive powers of the law to ensure that the high regard in which immunisation is held at the societal level receives appropriate weight at the point at which individual immunisation decisions are made.

Having established that it should be possible to achieve and sustain population immunity levels by targeting 'passively un-immunised' children whose parents have not made an active decision to remain outside our 'opt-in' National Immunisation Programme, three options for law reform are introduced and critically discussed: compulsory universal immunisation; a more or less stringent 'informed refusal' requirement; and a controversial proposal to link immunisation to the receipt of social security benefits.

The article concludes that reform is both desirable and practicable, but that striking the balance between individual freedom and the public good is more complex than the indisputable potential benefits of population immunity might suggest. Among the various issues which have to be navigated are the interplay between the individual and collective benefits and risks of immunisation; the imperative of maintaining public confidence in the integrity of State-mandated immunisation; and the allocation of decision-making rights (and responsibilities) between families and the State. At least for now, it is submitted that policy-makers should consider an 'opt-out' model whereby children are immunised, at the point of school entry at the latest, unless their parents successfully obtain a statutory exemption.

1 Ross D Silverman "No More Kidding Around: Restructuring Non-Medical Childhood Immunization Exemptions to Ensure Public Health Protection" (2003) 12 Ann Health L 277, 278

2 See Ministry of Health (National Immunisation Programme) Immunisation in New Zealand: Strategic Directions 2003-2006 (Wellington, 2003) 1 [Immunisation in New Zealand]; British Medical Association Childhood Immunisation: A Guide for Healthcare Professionals (British Medical Association Publications Unit, London, 2003) 1 [Childhood Immunisation]; United Kingdom Department of Health Immunisation Against Infectious Disease (London, 1996) Foreword [Immunisation Against Infectious Disease]; Ann Kempe Immunisation Programs in NZ, USA, Canada, UK and Finland: Lessons for Australia and South Australia (1998 Churchill Fellowship Report, Canberra, 1999) 17.

3 See Part II A 1 Population immunity. 


\section{INDIVIDUAL INTERVENTION, PUBLIC GOAL}

\section{A Introduction to Immunisation}

Immunisation, as considered in this article, describes the successful outcome (in about 95 per cent of cases) of a preventive medical intervention that utilises the immune response of children to build resistance to communicable diseases. ${ }^{4}$ As a "counter-intuitive biological process", 5 immunisation has never been universally embraced by health consumers. ${ }^{6}$ Yet it is regarded by the vast majority of health professionals and commentators, and this article proceeds on the basis that it is one of the most safe, ${ }^{7}$ cost-effective ${ }^{8}$ and successful ${ }^{9}$ health interventions ever developed.

\section{Population immunity}

Immunisation is conceptualised as a public health intervention because both the benefits and risks of individual immunisation decisions extend beyond an individual (and those immediately concerned with that individual's health) to their physical and economic community. ${ }^{10}$ Yet it is notoriously difficult to conceptualise these individual decisions as having broader significance. The diffuse benefits of immunisation have been compared to those of voting: a "single vote, or a single

4 Ministry of Health Immunisation Handbook 2002 (Wellington, 2002) 1-2 [Immunisation Handbook 2002]; Aphra Green "Immunisation in New Zealand: Patient Autonomy, Informed Consent, and the Code of Rights" (2002) 1 NZ Students' Law Jnl 203, 203; Steve P Calandrillo "Vanishing Vaccinations: Why are so Many Americans Opting Out of Vaccinating Their Children?" (2004) 37 U Mich J L Reform 353, 362-363; Australian Early Childhood Association "Immunisation" < http://www.earlychildhoodaustralia.org.au> (last accessed 18 April 2006). Most vaccinations relating to the nine diseases presently on New Zealand's National Immunisation Schedule are administered to children between the ages of six weeks and 15 months: Immunisation Handbook 2002, above n 4, 3, 243 and 274; Green, above n 4, 204.

5 Arthur Allen "Opposition to Vaccination Programs is Misguided" in William Dudley (ed) Epidemics (Greenhaven Press, San Diego, 1999) 'Vaccination and its Critics'.

6 See generally Immunisation Against Infectious Disease, above n 2, Foreword.

7 Steven P Shelov "Parents Should Not Be Allowed to Opt Out of Vaccinating Their Children" in Mary E Williams (ed) Vaccinations (At Issue Series, Greenhaven Press, San Diego, 2003) 'Introduction'.

8 See Immunisation Against Infectious Disease, above n 2, Foreword; Alan R Hinman and others "Childhood Immunisation: Laws that Work" (2002) 30 JLME 122, 122; Kempe, above n 2, 17; Immunisation in New Zealand, above n 2,1. Vaccine-preventable diseases are estimated to cost societies 16 times more than the vaccines that prevent them: Calandrillo, above n 4, 380

9 Calandrillo, above n 4, 358 and 369; Immunisation Against Infectious Disease, above n 2, Foreword; Immunisation in New Zealand, above n 2, 1.

10 See Kempe, above n 2, 17; Ministry of Health (National Health Committee) Review of the Wisdom and Fairness of the Health Funding Authority Strategy for the Immunisation of 'Hard to Reach' Children (Wellington, 1999) 2 [National Health Committee Review]; Immunisation in New Zealand, above n 2, 3; Ministry of Health Public Health Legislation Review: A New Public Health Legislative Framework: Discussion Document (Wellington, 1998) 15-16 [Public Health Legislation Review]; Childhood Immunisation, above $\mathrm{n} 2,5$. 
vaccination, is rarely going to make any difference. ... [But] as with voting, if everyone stops, the system collapses."11

The ultimate manifestation of this dilemma involves the phenomenon of "population immunity", the ultimate goal of any immunisation initiative. ${ }^{12}$ Since coverage rates of between 90 and 95 per cent of a population will effectively block the transmission of most diseases, ${ }^{13}$ it is sometimes assumed that the remaining 5 to 10 per cent can safely abstain from immunisation. However, the buffer provided by such "population immunity" thresholds is required to ensure protection for people who cannot physically receive vaccinations or for whom a vaccine simply fails. ${ }^{14}$ It may provide little or no scope for decisions to ignore or refuse immunisation.

\section{Risks}

No medical intervention is risk-free. However, of the majority of reported adverse events accepted as causally linked to immunisation, nearly all are foreseeable, self-limited, and considered to be overwhelmingly outweighed by the benefits associated with immunisation. ${ }^{15}$ While every vaccine is different, there is generally a "minute but measurable" risk of serious adverse reactions to vaccination, ${ }^{16}$ which is for almost all individuals "many hundreds or thousands of times less likely

11 Johnjoe McFadden "Injecting Some Sense" (21 January 2002) <http://www.guardian.co.uk> (last accessed 18 April 2006); see Public Health Legislation Review, above n 10, 15; Hinman and others, above n 8, 125; Calandrillo, above n 4, 420; Part VI B 2 Taking the easy way out.

12 See generally Kempe, above n 2, 18; Calandrillo, above n 4, 420; Childhood Immunisation, above n 2, 5; National Network for Immunization Information "Immunization Issues: Community Immunity" $<$ http://www.immunizationinfo.org $>$ (last accessed 18 April 2006).

13 Childhood Immunisation, above n 2, 5; Immunisation in New Zealand, above n 2, 2; National Network for Immunization Information, above n 12. While some diseases (the classic examples are smallpox and polio) may eventually be eradicated through immunisation, others (like meningococcal disease) can be sustained by protected, asymptomatic carriers and thus immunisation rates must be permanently maintained: see McFadden, above n 11; United States Centers for Disease Control and Prevention <http://www.cdc.gov> (last accessed 18 April 2006); Immunisation Against Infectious Disease, above n 2, Foreword; Childhood Immunisation, above n 2, 2; Ministry of Health Public Health Legislation: Promoting Public Health, Preventing Ill Health and Managing Communicable Diseases: Discussion Paper (Wellington, 2002) 35 [Public Health Discussion Paper].

14 See National Network for Immunization Information, above n 12; Childhood Immunisation, above n 2, 6; Kempe, above n 2, 18 .

15 See Immunization Action Coalition "It's Federal Law! You Must Give Your Patients Current Vaccine Information Statements (VISs)" < http://www.immunize.org> (last accessed 18 April 2006); Shelov, above $n$ 7, 'Introduction'; Immunisation Handbook 2002, above n 4, 48.

16 Chris Feudtner and Edgar K Marcuse "Ethics and Immunization Policy: Promoting Dialogue to Sustain Consensus" (2001) 107 Pediatrics 1158, 1160. 
than the risks associated with the diseases that the vaccines protect against." ${ }^{17}$ Unfortunately, harm attributed (whether or not attributable) to the vaccination of a healthy child attracts disproportionately more publicity than harm caused by naturally contracting a disease, especially once an immunisation initiative succeeds in lowering the likelihood of actually contracting that disease. ${ }^{18}$

\section{Opposition to immunisation}

Of the many reasons advanced for opposition to immunisation programmes, the question of what constitutes acceptable grounds for declining to participate in the collective endeavour to achieve population immunity is a difficult one. The worldwide anti-immunisation lobby is and continues to be extremely small; in New Zealand, between one and five per cent of parents oppose some or all vaccinations. ${ }^{19}$ But, aided by recent technological advances in information-sharing, the anti-immunisation lobby punches far above its weight. ${ }^{20}$

Scientific objections to immunisation, for example, tend to emphasise the inevitable margin of uncertainty by claiming that vaccines are more or less unsafe or ineffective. ${ }^{21}$ Another class of objections builds upon concerns about the competence and/or motivation of the State, sometimes amounting to allegations that vaccination is a conspiracy for profit or increased State control. ${ }^{22}$

17 Immunization Action Coalition, above n 15. See Shelov, above n 7, 'Introduction'; Immunisation Handbook 2002, above n 4, 141 and 260; Calandrillo, above n 4, 391; Tara Ross "Parents Flock to Infect Kids at 'Pox Parties"' (7 August 2005) The Manawatu Standard <http://www.stuff.co.nz> (last accessed 18 April 2006); Douglas S Diekema and American Academy of Pediatrics (Committee on Bioethics) "Responding to Parental Refusals of Immunization of Children" (2005) 115 Pediatrics 1428, 1430.

18 See Calandrillo, above n 4, 402-406; Diekema, above n 17, 1428; Immunisation Handbook 2002, above n 4 , 250

19 National Health Committee Review, above n 10, 6; National Health Committee "Action on Immunisation of New Zealand's 'Hard to Reach' Children" <http://www.nhc.org.nz> (last accessed 18 April 2006); Katherine Rich MP Saving the Next Generation from Welfare Dependency: Discussion Paper $<$ http://www.national.org.nz $>$ (last accessed 18 April 2006) 15 [Welfare Dependency Discussion Paper]. See generally Kempe, above n 2, 44; Daniel A Salmon "Mandatory Immunization Laws and the Role of Medical, Religious and Philosophical Exemptions" (Unpublished commentary, John Hopkins Bloomberg School of Public Health, 2003) 1.

20 Peter McIntyre, Alison Williams and Julie Leask "Refusal of Parents to Vaccinate: Dereliction of Duty or Legitimate Personal Choice?" (2003) 178 MJA 150. See generally Kempe, above n 2, 41; Calandrillo, above $n$ 4, 397-406.

21 See generally Calandrillo, above n 4, 402-403; Immunisation Handbook 2002, above n 4, 242.

22 See for example Calandrillo, above n 4, 397; New Zealand Anti-Vivisection Society "Vaccinations: General - The Conspiracy" <http://health.org.nz/artltitle.html > (last accessed 18 April 2006); Allen, above $n$ 5, 'Vaccination and its Critics'; Barbara Loe Fisher "Parents Should Be Allowed to Opt Out of Vaccinating Their Children" in Mary E Williams (ed) Vaccinations (At Issue Series, Greenhaven Press, San Diego, 2003) $<$ http://galenet.galegroup.com $>$ (last accessed 18 April 2006) Electronic unpaginated version available only [Fisher 1]. 
Much of this material is emotive and lacking in independent corroboration, ${ }^{23}$ but extremely difficult to counter with reasoned argument in light of powerful instincts to "first do no harm". ${ }^{24}$ It is particularly hard to know how far policy-makers should go in countering, or possibly suppressing, misguided or deliberately misleading immunisation information. ${ }^{25}$

\section{B Why the Law Gets Involved}

The staggering past successes of immunisation should not obscure the fact that most of the diseases it has or could potentially target are not yet under control, because not enough people are participating in immunisation programmes. ${ }^{26}$ Whether, and how, the State should accept responsibility for controlling vaccine-preventable disease in the absence of an effective popular response is largely a question of political philosophy. The options range from not hindering people in accessing immunisation, to the active promotion of immunisation, to a decision to implement immunisation goals by coercive means. Whichever route is taken, sound immunisation policy should explicitly acknowledge which interests are to be prioritised and which harms considered acceptable, in the pursuit of population immunity: to preserve both the integrity of an immunisation programme and the public's perception of its integrity. ${ }^{27}$

\section{Some Dilemmas in Immunisation Policy}

1 Out of sight, out of mind

While immunisation can be "seen as an issue straddling the boundary between 'purely' medical issues and those of lifestyle choice or upbringing", ${ }^{28}$ commentators stress that individual decisions

23 Calandrillo, above n 4, 398 and 402-403; Childhood Immunisation, above n 2, 15 and 19; National Network for Immunization Information "Parents: Evaluating Information on the Web" $<$ http://www.immunizationinfo.org $>$ (last accessed 18 April 2006). For a New Zealand example, see The Immunisation Awareness Society Inc "My Child Suffered an Adverse Reaction" and "Adverse Reactions: More Stories and Links" <http://www.ias.org.nz> (last accessed 18 April 2006).

24 See for example Calandrillo, above n 4, 405; Childhood Immunisation, above n 2, 8, 15 and 20; James Meikle "Court Win for Fathers in MMR Jabs Fight" (14 June 2003) The Guardian <http://www.guardian.co.uk> (last accessed 18 April 2006); Clare Dyer "Judge Overrules Mothers' Objections to MMR Vaccine" (2003) 326 BMJ 1351, 1351.

25 See Part VI A 2 Countering misinformation.

26 See generally Childhood Immunisation, above n 2, 1; Mountain State Centers for Independent Living "Support Mandatory Immunizations!" <http://www.mtstcil.org> (last accessed 18 April 2006); McFadden, above $n 11$.

27 See Hinman and others, above n 8, 122; Part IV C Practical Considerations. See generally American Academy of Pediatrics "Testimony Statement of Samuel L Katz MD to the Committee on Government Reform, U.S. House of Representatives, August 3 1999" <www.aap.org/advocacy> (last accessed 18 April 2006); Kath O'Donnell "Re C (Welfare of Child: Immunisation): Room to Refuse? Immunisation, Welfare and the Role of Parental Decision-Making" (2004) 16 C Fam 213; Calandrillo, above n 4, 356.

28 O'Donnell, above n 27, 'Childhood Immunisation and the MMR Debate'. 
should at least incorporate a comparison of vaccination risk with the risk of actually contracting the relevant disease. ${ }^{29}$ Yet many parents, perhaps overwhelmed by the complexity of immunisation science, growing societal complacency as the threat posed by a dormant (but not extinct) disease fades from memory, and the disproportionate visibility of vaccinations gone bad, never make this comparison. ${ }^{30}$ Should the State do so, and make the 'rational' decision to proceed with immunisation, on their behalf?

\section{Individual freedom}

Any governmental move to implement immunisation can be seen as restricting individual freedom. Advocacy, or mandating, of individual choice removes freedom to avoid the issue. Making immunisation compulsory, or limiting the grounds upon which it may be refused, would impact more directly (and controversially) on autonomy interests. The line between individual freedom and public good must be drawn somewhere: "Is a single case prevented worth 10 immunized unwillingly? Or is the threshold 100 or even $1000 ?^{\prime 31}$

\section{Children}

Children under two years of age form the primary focus of immunisation initiatives. This is considered ethically acceptable, given immunisation is "effective, minimally invasive, and associated with significant societal benefits." 32 It is considered imperative because children, for whom States have an acknowledged special responsibility, tend to be more susceptible to, and more seriously harmed by, vaccine-preventable diseases. ${ }^{33}$

That said, the "care of children is primarily regarded as part of a 'private' domain outside of the public and economic spheres". ${ }^{34}$ Policy-makers must be prepared to prioritise, if necessary, either

29 See for example Immunisation Handbook 2002, above n 4, 250; Kempe, above n 2, 41.

30 See Calandrillo, above n 4, 402-406; Childhood Immunisation, above n 2, 6 and 18.

31 Feudtner and Marcuse, above n 16, 1163.

32 McIntyre, Williams and Leask, above n 20, 150.

33 Australian Early Childhood Association, above n 4. See Ministry of Health Well Child Tamariki Ora Health Book (Revised, Wellington, 2005) 14 [Well Child]; Childhood Immunisation, above n 10, 6. See generally Public Health Discussion Paper, above n 13, 28; Convention on the Rights of the Child (20 November 1989) 1577 UNTS 3.

34 John Angus "The Code of Social and Family Responsibility as a Family Policy Initiative" in Judith A Davey (ed) Another New Zealand Experiment: A Code of Social and Family Responsibility (Institute of Policy Studies, Wellington, 2000) 137, 147. See John Eekelaar Family Law and Social Policy (2 ed, Weidenfeld and Nicolson, London, 1984) 190, 198. See generally Childhood Immunisation, above n 2, 13; McIntyre, Williams and Leask, above n 20, 150; Ross D Silverman and Thomas May "Private Choice Versus Public Health: Religion, Morality, and Childhood Vaccination Law" (2001) 1 Margins 505, 518-519. 
parents' interests in controlling the immunisation status of their child or that child's interest, shared by the broader community, in receiving immunisation.

\section{IMMUNISATION IN NEW ZEALAND}

Immunisation is considered of central importance in the discharge of the "core public health function" of prevention and control of communicable disease in New Zealand. ${ }^{35}$ The Ministry of Health has overall responsibility for immunisation policy and delivery, with potentially conflicting roles including vaccine purchase, monitoring and auditing, and "strategies for improving coverage". 36

\section{A The Story so Far}

In the last century, New Zealand's National Immunisation Programme has impelled a "dramatic decline" in vaccine-preventable disease. ${ }^{37}$ However, it has consistently failed to achieve official immunisation targets (including the current one of comprehensive immunisation of 95 per cent of two year olds). ${ }^{38}$ That this is not an inevitable consequence of conflicting policy considerations and interests is apparent from the Ministry of Health's bleak concession, in 2003, that compared "with other developed countries our immunisation coverage at age two years is low". 39

How can our ongoing difficulty in raising coverage rates be explained? The foundation for accessible immunisation has been laid; for example, all routine childhood vaccines are free, ${ }^{40}$ which should prevent parents from deciding for economic reasons to forego immunisation in favour of other health services. More crucially for law reform purposes, the large number of fully or partially un-immunised children cannot be accounted for by the small number of parents who actively oppose immunisation. This means that there are many children who are, for whatever reason, effectively falling through the gaps.

The phenomenon of 'passive' non-immunisation thus isolated is a grim one: the increased vulnerability of these children is not even ameliorated, as in the case of 'actively' un-immunised children, by vindication of their parents' autonomy interests. Yet assuming opposition to

35 Public Health Legislation Review, above n 10, 37. See Immunisation in New Zealand, above n 2, Foreword; Immunisation Handbook 2002, above n 4, 267. See generally Convention on the Rights of the Child, above n 33, art 24 (particularly art 24(2)(c) and (e)).

36

Immunisation Handbook 2002, above n 4, 276-277.

37 Immunisation in New Zealand, above n 2, vi.

38 Immunisation in New Zealand, above n 2, vi, 2 and 5; Ministry of Health Progress on Health Outcome Targets 1998 (Wellington, 1998) 75-80 [Progress on Health Outcome Targets 1998].

39 Immunisation in New Zealand, above n 2, 1. See Public Health Discussion Paper, above n 13, 33.

40 Immunisation Handbook 2002, above n 4, 4. See Immunisation in New Zealand, above n 2, 8; McIntyre, Williams and Leask, above n 20, 150; Feudtner and Marcuse, above n 16, 1159. 
immunisation does not approach or overtake the population immunity buffer, it is also encouraging. Eliminating passive non-immunisation and achieving population immunity should be possible without resort to coercion.

\section{Who are the passively un-immunised?}

It is well-documented that clusters of un-immunised children hamper disease control efforts. ${ }^{41}$ As a result of the prevalence of passive non-immunisation in certain socio-economic and ethnic groups (particularly Māori and Pasifika), the Ministry of Health has conceded that our immunisation coverage is not only low, but inequitably distributed. ${ }^{42}$ This is doubly concerning: it renders certain children more vulnerable to disease, and produces 'hot spots' which allow diseases to sustain themselves within the population. ${ }^{43}$

\section{B Policy, 'Law' and Reform?}

In New Zealand, "healthy public policy" in respect of immunisation is firmly anchored to the idea of informed parental consent. ${ }^{44}$ Accordingly, the role of our legal system has been primarily facilitative (focused on removing barriers to uptake of immunisation), not prescriptive or coercive. ${ }^{45}$ Yet a comparison, sustained throughout this article, with countries which share our basic commitment to parental consent (particularly Australia and the United States) reveals that the involvement of New Zealand's formal legal institutions in immunisation has been unnecessarily muted.

\section{Health (Immunisation) Regulations 1995}

The sole legal instrument focused upon immunisation is the Health (Immunisation) Regulations 1995 ("the Regulations"). In summary, the Regulations link childhood immunisation to education by "requir[ing] early childhood centres and primary schools to require information from caregivers in the form of immunisation certificates regarding the immunisation status of children."46

The current Immunisation Handbook asserts that the Regulations compel parents to make informed choices about immunisation. ${ }^{47}$ This is untrue. Making an informed choice is not a legal

41 National Health Committee Review, above n 10, 2; Calandrillo, above n 4, 361; Allen, above n 5, 'Risking More Outbreaks'; McIntyre, Williams and Leask, above n 20, 151.

42 Immunisation in New Zealand, above $\mathrm{n} 2$, vi.

43 See generally Calandrillo, above n 4, 361; National Health Committee Review, above n 10.

44 See Immunisation in New Zealand, above n 4, 19; Immunisation Handbook 2002, above n 4, 32-35.

45 See Standard 10 in Immunisation Handbook 2002, above n 2, 281; Immunisation in New Zealand, above n 2 , 6 and 19.

46 Green, above n 4, 209.

47 Immunisation Handbook 2002, above n 4, 283. See Well Child, above n 33, 14. 
precondition to providing a certificate (which may simply record a child as un-immunised). ${ }^{48}$ Further, there is no incentive for parents to make an informed choice as opposed to a casual or default one. Enrolment is expressly not contingent upon the production of a certificate, and the only sanction for children whose parents have not opted in to immunisation - potential temporary exclusion upon the outbreak of disease - applies whether or not that child is 'actively' unimmunised. ${ }^{49}$

\section{National Immunisation Register}

Consistent with increasing acceptance that a centralised vaccination register is an "essential component" of an effective immunisation programme, ${ }^{50}$ the most significant recent policy initiative has been the introduction of the National Immunisation Register. ${ }^{51}$ The Ministry of Health has claimed not only that the Register will provide accurate individual and general statistics but that it will eventually eliminate passive non-immunisation. ${ }^{52}$

It is certainly hard to see the Register as a step in the wrong direction. Having robust information on coverage rates will assist regional and national planning, and a reminder system may largely overcome the problem of parental ignorance of the availability of routine vaccinations. However, although the Ministry envisages a relatively aggressive approach to targeting children overdue for scheduled immunisation events (extending to opportunistic vaccination whenever a child makes contact with the health system), ${ }^{53}$ the Register does not restrict the ability of parents to withhold their children from specific vaccinations or the entire programme. Accordingly, it may do little to address ostensibly deliberate non-participation that is founded upon hostility to government, myths about immunisation science, or nothing specific.

\section{Public health reform}

"Rumblings" about bringing our immunisation laws into conformity with comparable countries have long been circulating, ${ }^{54}$ and new public health legislation now seems likely to eventuate from a

48 See Green, above n 4, 209.

49 Health (Immunisation) Regulations 1995, reg 12. See Ministry of Health Consent in Child and Youth Health: Information for Practitioners (Wellington, 1998) 25; Progress on Health Outcome Targets 1998, above n 38,80 . See further Part IV C 2 The school entry issue.

50 Kempe, above n 2, 31. See also Ministry of Health Overview of the National Immunisation Register (Wellington, 2004) 1 [Overview of the National Immunisation Register].

51 See generally Overview of the National Immunisation Register, above n 50.

52 Immunisation in New Zealand, above n 2, 7. See Overview of the National Immunisation Register, above $\mathrm{n}$ 50,3 .

53 Overview of the National Immunisation Register, above n 50, 3-6.

54 New Zealand Anti-Vivisection Society, above n 22. 
general overhaul of the Health Act $1956 .{ }^{55}$ This legislation is likely to reflect "recognition of the importance of protecting human rights, but also agreement that giving greater value to protection of the public health [is] justified in some circumstances." ${ }^{56}$ While a number of contemplated provisions refer to immunisation, the crucial proposal for present purposes focuses upon the obligations of parents. ${ }^{57}$ It is proposed that generally phrased provisions in the Health Act could empower (without mandating) regulations to implement anything from the status quo under the Regulations, to certification requiring an acceptable reason for refusing immunisation, to empowerment for schools to refuse a child's enrolment without certification. ${ }^{58}$

It has been said that coercive public health legislation is a "last resort". ${ }^{59}$ If the State considers that this point has already been reached with immunisation, regulations should be mandated, not enabled. If not, empowering provisions risk conveying the contrary impression. In any event, substantive restriction of parental choice (as opposed to the detailed implementation of any restriction) is arguably not appropriately effected within delegated legislation, but should be articulated and defended at the highest level. ${ }^{60}$

\section{Summary}

When it is recognised that passive non-immunisation is the dominant cause of our failure to reach immunisation targets, it is submitted that whether or not the basic 'opt-in' structure of our National Immunisation Programme is retained, there is room for improvement. At a minimum, what is required is a commitment to ensuring that all parents who do not actively oppose immunisation actually reach the stage of effecting the full immunisation of their children.

\section{MANDATORY IMMUNISATION}

In New Zealand, requiring parents to submit their children to immunisation is not currently considered to be a realistic option. ${ }^{61}$ Yet, both here and overseas, universal, State-mandated immunisation (for all children except those medically contra-indicated) continues to be advanced by

55 See Public Health Legislation Review, above n 10; Public Health Discussion Paper, above n 13.

56 Public Health Discussion Paper, above n 13, 6.

57 See Public Health Discussion Paper, above $\mathrm{n}$ 13, $\mathrm{x}$ and 33.

58 Public Health Discussion Paper, above n 13, 34-35.

59 See Public Health Legislation Review, above n 35, 16.

60 See generally Geoffrey Palmer and Matthew Palmer Bridled Power: New Zealand's Constitution and Government (4 ed, Oxford University Press, Melbourne, 2004) 207-212.

61 See III B Policy, 'Law' and Reform? For similar policy positions in comparable Western countries, see McIntyre, Williams and Leask, above n 20, 151; Childhood Immunisation, above n 2, 16-18 and 20. 
some as the most efficient and effective means of achieving population immunity. ${ }^{62}$ This part outlines why it continues to be difficult to argue that the interest of the State in controlling preventable disease outweighs the interest of individuals in being free to refuse immunisation.

\section{A The Right to Refuse Immunisation?}

In Western democracies, there exists a fundamental societal expectation (now strengthened by constitutional statutes codifying certain rights and freedoms) that the right of individuals to behave as autonomous agents will be respected. ${ }^{63}$ However tempting it is to conceptualise immunisation as a public endeavour, it is performed upon individuals who must, as individuals, bear its consequences. Viewed in this light, New Zealand's human rights commitments may found a constitutional right for individuals to refuse immunisation.

First and foremost among these commitments is the significance accorded to individuals' bodily integrity, ${ }^{64}$ defined relevantly for present purposes as the rights of informed consent to medical interventions ${ }^{65}$ and to refuse medical treatment. ${ }^{66}$ Vaccinations administered to healthy children may not be 'treatments' but are undoubtedly 'interventions', meaning that New Zealanders have a right not only to refuse them but also to expect that they will not be administered in the absence of prior informed consent.

A right to refuse immunisation does not have to be constructed by reference to bodily integrity, however. For example, a mandatory immunisation law would arguably undermine protected rights to freedom of religion, culture and belief. ${ }^{67}$ Even if a child was oblivious to the implications of an

62 See Childhood Immunisation, above n 2, iv and 16-20. For examples of advocacy for mandatory immunisation, see Shelov, above n 7; Silverman and May, above n 34; Sarah Boseley "Cubans Tell NHS the Secret of $£ 7$ a Head Healthcare" (2 October 2000) The Guardian <http://www.guardian.co.uk> (last accessed 18 April 2006); Mountain State Centers for Independent Living, above n 26.

63 See Jonathan Boston "Social Justice and the Welfare State" in Jonathan Boston, Paul Dalziel and Susan St John (eds) Redesigning the Welfare State in New Zealand: Problems, Policies, Prospects (Oxford University Press, Auckland, 1999) 20, 20-21. See generally New Zealand Bill of Rights Act 1990; Human Rights Act 1993; Privacy Act 1993; Universal Declaration of Human Rights (10 December 1948) UNGA Resolution 217 A (III).

64 See Calandrillo, above n 4, 393-394; Public Health Legislation Review, above n 10, 24-25.

65 See Health and Disability Commissioner (Code of Health and Disability Services Consumers' Rights) Regulations 1996, 1st sch, cl 2 Right 7(1). See generally Health and Disability Commissioner Act 1994; Privacy Act 1993; Public Health Legislation Review, above n 10, 24; American Academy of Pediatrics (Committee on Bioethics) "Informed Consent, Parental Permission, and Assent in Pediatric Practice" (1995) 95 Pediatrics 314.

66 See New Zealand Bill of Rights Act 1990, s 11. See generally American Academy of Pediatrics (Committee of Bioethics), above n 65, 315; Public Health Legislation Review, above n 10, 24.

67 See New Zealand Bill of Rights Act 1990, ss 13, 15 and 20; Part VI B 3 Drawing the line. 
immunisation requirement, it could be seen to undermine the parents' ability to manifest their beliefs in the bringing up of their children, representing a "clear loss of personal freedom" for the whole family. 68

Rights not to be deprived of life and/or not to be subjected to experimentation are sometimes invoked as underpinning a right to refuse immunisation. ${ }^{69}$ However, a mandatory law could only infringe those rights if the current risks of immunisation were accepted as grossly underestimated or understated.

\section{B The Right to Demand Immunisation?}

Rights, including any prima facie right to refuse immunisation, are not guaranteed absolute protection. For instance, the rights affirmed in the New Zealand Bill of Rights Act 1990 are subject to "demonstrably justified" limitations, ${ }^{70}$ and the International Covenant on Civil and Political Rights contemplates limitations on freedom of religion to protect "public safety, order, health, or morals or the fundamental rights and freedoms of others". ${ }^{71}$ Thus, our Court of Appeal has defined the rights of Jehovah's Witness parents to freedom of religion and to refuse medical treatment for their child to "exclude doing or omitting anything likely to place at risk the life, health or welfare of their children." 72

In fact, it may be possible to reverse the argument and construct a positive right to immunisation, given every New Zealander has a right to the highest attainable standard of health. ${ }^{73}$ This is normally subject to the right to refuse medical treatment and does not give rise to a corresponding obligation upon individuals to be healthy. However, it arguably obligates, first, the government to

68 Feudtner and Marcuse, above n 16, 1163. See Re J (an infant): B and B v D-G of Social Welfare [1996] 2 NZLR 134, 145 (CA) Gault J for the Court; Convention on the Rights of the Child, above n 33, art 14.

69 See for example Fisher 1, above n 22; Barbara Loe Fisher (National Vaccine Information Center) "The Moral Right to Conscientious, Personal Belief or Philosophical Exemption to Mandatory Vaccination Laws" (1997) <http://www.909shot.com> (last accessed 18 April 2006) Electronic un-paginated version available only [Fisher 2]; New Zealand Anti-Vivisection Society, above n 22.

70 New Zealand Bill of Rights Act 1990, s 5.

71 International Covenant on Civil and Political Rights (19 December 1966) 999 UNTS 171, art 18(3) (emphasis added). See $\operatorname{Re} J$ (an infant): $B$ and $B v D$ - $G$ of Social Welfare, above n 68, 145 Gault $\mathrm{J}$ for the Court. See further Salmon, above n 14, 2, emphasising that mandatory immunisation is not considered to "violate the First Amendment right to free exercise of religion" in the United States.

$72 \operatorname{Re} J$ (an infant): $B$ and Bv D-G of Social Welfare, above $\mathrm{n}$ 68, 146 Gault $\mathrm{J}$ for the Court.

73 International Covenant on Economic, Social and Cultural Rights (19 December 1966) 993 UNTS 3, art 12. 
provide the necessary conditions for its fulfilment, ${ }^{74}$ and secondly, other individuals not to hamper its exercise.

On this basis, it is arguable that withholding (even preventive, rather than life-saving) immunisation from a child denies their right to health. ${ }^{75}$ More broadly, it can be argued that a refusal to participate in immunisation is essentially a selfish decision that undermines the collective right of others to improve their community's overall health. ${ }^{76}$ This can also be conceptualised as a right of future generations to be free from the threat of preventable disease. ${ }^{77}$

\section{Immunisation as a public duty?}

Leaving aside the argument that the State is not acting as an 'enemy' of the public or of individuals who it compels to be immunised (since immunisation serves the interests of both), some commentators have described immunisation as a "public duty" to current and future generations. ${ }^{78}$ In this respect, it is noted that although immunised individuals (unlike everyone else) are not physically endangered by others' refusal of immunisation, they can still be "harmed by the cost of medical care for those who choose not to immunize their children and whose children then contract vaccine-preventable disease." 79 It has even been suggested that immunisation constitutes a prerequisite to membership of a responsible society, analogously with accepted obligations to contribute to (for example, by paying tax) or not to detract from (for example, by respecting traffic laws drafted to avoid accidents) the public good. ${ }^{80}$

74 International Covenant on Economic, Social and Cultural Rights, above n 73, art 12(2)(c) states that steps to be taken by State parties to implement the right to health include those necessary for the "prevention, treatment and control of epidemic ... and other diseases".

75 See National Health Committee Review, above n 10; P Bradley "Should Childhood Immunisation be Compulsory?" (1999) 25 JME 330, 333; The Health and Disability Commissioner "Informed Choice and the Rights of Children" (10 February 2000)<http://www.hdc.org.nz> (last accessed 18 April 2006); O'Donnell, above $\mathrm{n} 27$, footnote 6 and accompanying text.

76 See Silverman and May, above n 34, 520-521; Philippe Beutels "On Mandatory Vaccination" <http://www.bmj.bmjjournals.com> (last accessed 18 April 2006); Bradley, above n 75, 332-333; Felicity Lawrence "The Battle Over Immunisation" (10 August 2001) The Guardian <http://www.guardian.co.uk> (last accessed 18 April 2006); Hinman and others, above n 8, 126.

77 See United States Department of Health and Human Services (Centers for Disease Control and Prevention) "For Parents: Why Immunize?" <http://www.cdc.gov> (last accessed 18 April 2006); Bradley, above n 75, $332-333$.

78 See for example E Vermeersch "Individual Rights Versus Societal Duties" (1999) 17 Vaccine S14; Beutels, above n 76. But see New Zealand Health Trust Public Health Legislation Discussion Paper (submission to Ministry of Health, 2003) 5.

79 Diekema, above n 17, 1429.

80 See United States Department of Health and Human Services (National Vaccine Program Office) "Immunization Laws" <http://www.cdc.gov> (last accessed 18 April 2006); Diekema, above n 17, 1429; 


\section{The numbers game}

The small number of parents opposed to immunisation weighs in on both sides of the debate. On one hand, the overwhelming degree of support for immunisation in principle bolsters arguments that any concession to individual freedom demonstrates an irrational willingness to tolerate harm to all in order to avoid harm to a few. On the other hand, any suggestion that State-mandated immunisation is a reasonable corollary of citizenship deserves close scrutiny, simply because there are people who would otherwise be considered responsible citizens that do not share this view.

\section{Practical Considerations}

Even if mandatory immunisation was thought to be compatible with New Zealand's human rights commitments, translating it into an effective and sustainable legal framework would be a daunting task. ${ }^{81}$ While in principle Parliament's power may be unlimited, in practice it is constrained by the need for law to be palatable to the public that elects the enacting government and, crucially, its successors. Calandrillo has warned that "using absolute mandates to increase immunization levels is probably not a wise social policy, and could produce a serious backlash." 82

Legislative removal of freedom of choice would hopefully be based on an assumption that rational, informed citizens would choose immunisation, but that allowing diseases to persist while that realisation dawns upon everyone is unacceptable. Unfortunately, people might reason that there would have been no need to remove it unless rational people might choose to reject immunisation. ${ }^{83}$

As Bradley has suggested, if parents are excluded from one decision, the likelihood of their compliance with subsequent immunisation and other health interventions may be decreased. ${ }^{84}$ Promotional resources currently devoted to overcoming "parental inertia" in respect of immunisation ${ }^{85}$ might still be required to maintain short and long-term support for the law by continually highlighting its democratic foundation and ultimate objectives.

Hinman and others, above n 8, 126; United States Department of Health and Human Services (Centers for Disease Control and Prevention), above n 77; Dr Don Brash MP "Brash Responds to Maharey" (31 January 2005) Media Release. See generally Lawrence M Mead Beyond Entitlement: The Social Obligations of Citizenship (Macmillan, New York, 1986) 12.

81 See Childhood Immunisation, above n 2, 16; Immunisation Against Infectious Disease, above n 2, Foreword; Feudtner and Marcuse, above n 16, 1163. Compare Hinman and others, above n 8, 123.

82 Calandrillo, above n 4, 437.

83 Fisher 2, above n 69.

84 Bradley, above n 75, 331.

85 See National Health Committee Review, above n 10, 30. 


\section{How do you enforce an immunisation law?}

To successfully overcome parental opposition, it would have to be more onerous to defy or ignore an immunisation law than to comply with it. Yet given any law would be intended to enhance, not diminish, people's ability to live free and productive lives, it is difficult to conceptualise a sanction that would be appropriately serious without being unduly punitive. In Belgium, children can be temporarily removed from their parents' guardianship following refusal of the polio vaccine. ${ }^{86}$ Apart from being likely to attract vociferous opposition if proposed today, such disruption of the family environment seems needlessly heavy-handed. As another example, it has been suggested that parents who reject immunisation "should pay the full costs of any health care resulting from that decision." ${ }^{87}$ Like proposals to withhold benefit payments, ${ }^{88}$ such monetary sanctions would have the flow-on effect of punishing the very children they were intended to protect.

\section{The school entry issue}

Most countries that have adopted some form of coercive immunisation law have accepted, in practice, that the immunisation status of children is a legitimate basis upon which to discriminate between them. In the United States, for example, every state prevents schools from accepting unimmunised children unless their parents successfully navigate a statutory exemption process. ${ }^{89} \mathrm{In}$ most Western countries, including New Zealand (although this is a protective rather than punitive measure), un-immunised children can be excluded from school upon an outbreak of disease. ${ }^{90}$

School immunisation laws have received some heavy criticism. They can constitute "implicit (inequitable) coercion" for those actively opposed to immunisation, by setting up an inescapable conflict between the interests of parent and child. ${ }^{91}$ Further, any eventual deterrent effect comes at the expense of children who are already vulnerable by being un-immunised, and who, as recognised

86 Beutels, above n 76.

87 Department of Social Welfare Towards a Code of Social and Family Responsibility: The Response Report (Wellington, 1998) 47.

89 See Calandrillo, above n 4, 355-357; Salmon, above n 19, 1; Silverman, above n 1, 280-284; M Craig Smith "A Bad Reaction: A Look at the Arkansas General Assembly's Response to McCarthy v Boozman and Boone v Boozman" (2005) 58 Ark L Rev 251, 251.

90 See National Network for Immunization Information "Common Questions about School Immunization Laws" < http://www.immunizationinfo.org> (last accessed 18 April 2006); McIntyre, Williams and Leask, above n 20, 150; Childhood Immunisation, above n 2, 17-18; Part III B 1 Health (Immunisation) Regulations 1995.

91 Beutels, above n 76. 
in the Education Act 1989, ${ }^{92}$ are incapable of insisting on the fulfilment of their fundamental right to education. ${ }^{93}$

Yet it is precisely the mandatory nature of school attendance that makes new entrants an ideal target for immunisation initiatives. A United States expert has emphasised that "school laws establish a system for immunization, a system that works year in and year out, regardless of political interest, media coverage, changing budget situations, and the absence of vaccine-preventable disease outbreaks to spur interest." 94

The State's obligation to educate children can be seen as a corollary of its right to demand that those children fulfil their potential as citizens by becoming educated. One un-immunised child poses a demonstrable short-term risk to others in their class. More fundamentally, a child is more likely to suffer a compromised or terminated education as the result of contracting a vaccine-preventable disease than from being excluded until their parents comply with immunisation laws. School-entry requirements can, therefore, be seen as representing an appropriate balance between the right to education and the rights and obligations of governments in respect of the provision of that education. ${ }^{95}$

\section{Emergencies}

The one scenario in which the Ministry of Health considers a mandatory immunisation law might be justified is as an urgent measure to combat an "extreme threat". ${ }^{96}$ The normal requirement of prior informed consent ${ }^{97}$ could be diluted by authorising the vaccination of those people for whom "efforts made to obtain consent have failed or obtaining consent is not practicable in the circumstances." 98

92 See Education Act 1989, s 20.

93 See Department of Social Welfare, above n 87, 47; New Zealand Health Trust, above n 78, 20; Methodist Mission (South Island) Social Comment from the Mission: Towards a Code of Social and Family Responsibility (submission to Department of Social Welfare, 1998) 'Issue 3: Keeping Our Children Healthy'. For the right of children to an education generally, see Education Act 1989, s 3; Convention on the Rights of the Child, above n 22, art 28(1).

94 Dr Walter Orenstein, Director of the National Immunization Program, United States Centers for Disease Control and Prevention, quoted in Salmon, above n 19, 1 .

95 See Hinman and others, above n 8, 126.

96 Public Health Discussion Paper, above n 13, 33. See generally Calandrillo, above n 4, 384; Jacobson v Massachusetts (1905) 197 US 11 (where the State of Massachusetts' police power to protect the public's health was held by the Supreme Court to include the right to require that all citizens of the city of Cambridge receive a smallpox vaccination during an outbreak).

97 See Immunisation Handbook 2002, above n 4, 32.

98 Public Health Discussion Paper, above n 13, 35. 
Although this prospect might seem even more alarming than a universal immunisation requirement, in that normal procedural safeguards could potentially be dispensed with, there are several reasons why it is likely to be viewed as less oppressive than a 'peacetime' law. First, although still a preventive measure, both the connection between action (vaccination) and consequence (survival) and the comparison between vaccine and disease risk are easier for individuals to draw if a disease is wreaking present havoc. Secondly, the Ministry's focus is squarely on terrorist-introduced disease. ${ }^{99}$ People are more likely to engage with the selfless, collective benefits of immunisation if they can conceptualise it as a war against a visible opponent - terrorists, manufactured disease, or both. Finally, emergency vaccinations would be administered to adults as well as, or possibly instead of, children, negating suspicion that the State relies upon children's powerlessness to implement immunisation for its own ends.

\section{MANDATORY INFORMED DECISIONS}

Accepting that the power to make decisions about immunisation should generally rest with individuals, rather than the State, does not mean that the State has to withdraw from the decisionmaking process altogether. While any law that attempts to strike a balance between individual freedom and public good must not have the effect of removing individuals' ability to make a decision, it may legitimately prevent them from not making a decision. Indeed, given the everpresent danger of confusion and misinformation, it is not clear that a requirement merely to communicate a decision will be sufficient to eliminate passive non-immunisation.

We have seen that the New Zealand system is effectively an 'opt-in' one. The State stresses the importance of making a choice, and immunisation is promoted as safe and normal. However, the default position is that providers must not proceed with immunisation in the absence of express consent. Further, there are no sanctions for unreasonable failure to give this consent, which may mean that it appears easier to ignore or refuse immunisation than to accept it.

There is another way. An 'opt-out' or 'exemption' system - of which the United States is the most famous example - creates a legal presumption in favour of immunisation, at the point of enrolment in primary school, which requires some degree of individual effort to displace. There is enormous scope for variation in the structure of an exemption scheme; a relatively weak version was flagged in the recent public health discussion papers. ${ }^{100}$ In New Zealand, given that informed consent is (supposedly) the touchstone for opting in to immunisation, it seems logical to consider whether informed refusal might be required in order to opt out. ${ }^{101}$

99 Public Health Discussion Paper, above n 13, 35.

100 See Part III B 3 Public health reform.

101 Silverman, above n 1, 294. 


\section{A The Content of Informed Decisions}

Consent to medical interventions in New Zealand is regarded as an ongoing process rather than an isolated event. As embodied in the Code of Health and Disability Consumer's Rights (Code), ${ }^{102}$ the process: ${ }^{103}$

... necessarily involves effective communication in a form, language, and manner that enables the consumer to understand the information provided. It also involves provision of all necessary information, including information about options, risks, side-effects, benefits and costs.

A key point to emphasise is that an informed decision does not mean an objectively correct decision, but rather one made freely on the basis of appropriate information. ${ }^{104}$ Unless we are prepared to assert that it is not possible for an informed, competent consumer to refuse immunisation (in which case there seems no reason not to seriously consider mandatory immunisation), caution is required in impliedly equating an informed decision to an acceptance of immunisation.

\section{B Who Makes the Choice for Children?}

\section{Children and consent to medical interventions}

The paradigm of informed consent does not operate perfectly in the immunisation context, simply because most immunisation 'consumers' are young children. ${ }^{105}$ On the assumption that the inchoate developmental status of children denies them the capacity to consent to medical interventions, the Care of Children Act 2004 authorises a legal guardian to consent on their behalf. ${ }^{106}$ Given New Zealand practitioners "appear to have presumed an obligation to obtain parental consent if a child is under $16 ",{ }^{107}$ parental refusal of immunisation could conceivably be overridden only in a life-threatening emergency or by order of a court. ${ }^{108}$

102 Health and Disability Commissioner (Code of Health and Disability Services Consumers' Rights) Regulations 1996 (particularly 1st sch, cl 2, rights 5, 6 and 7).

103 Green, above n 4, 204. See also Immunisation Handbook 2002, above n 4, 32-35; Immunisation Against Infectious Disease, above n 2, 2; The Health and Disability Commissioner "What Do I Need to Know about 'Informed Consent'?" (30 June 2005) <http://www.hdc.org.nz> (last accessed 18 April 2006).

104 American Academy of Pediatrics (Committee on Bioethics), above n 65, 314-315; The Health and Disability Commissioner, above n 103

105 See American Academy of Pediatrics (Committee on Bioethics), above n 65, 314.

106 Care of Children Act 2004, s 36(3).

107 Immunisation Handbook 2002, above n 4, 34 (emphasis added). See Green, above n 4, 204-205.

108 See John Dewar Law and the Family (Butterworths, London, 1989) 73. Compare Immunisation Handbook 2002, above n 4, 278. 
This does not mean that children are irrelevant, except as physical participants, to the immunisation process. The inability of children to make informed decisions does not affect their right to "have their views considered in matters that affect them", ${ }^{109}$ and health professionals must ensure that children are informed according to their ability and level of understanding. ${ }^{110}$

\section{The 'right' of parents to make immunisation decisions}

Parents may be free to become martyrs themselves. But it does not follow that they are free, in identical circumstances, to make martyrs of their children before they have reached the age of full and legal discretion .... ${ }^{111}$

It is often assumed that parents or caregivers are not only ideally placed to make, but have a right to make immunisation decisions for their children. ${ }^{12}$ In fact, the parental decision-making role now tends to be characterised - reflecting a shift towards consideration of children as citizens, rather than mere extensions of their parents - more as a "responsibility or power" than a right. ${ }^{113}$ Despite consensus that the raison d'etre of this power is the best interests of the child, ${ }^{114}$ there is disagreement over both the meaning and content of best interests and how tightly parental decisionmaking is constrained by reference to it. ${ }^{115}$ On one view, parents have no power to make decisions that are not in their child's best interests. In reality, this is not enforced (or enforceable) beyond the prohibition of parental abuse and neglect. ${ }^{116}$ On another view, shared by the majority of

109 Ministry of Social Development New Zealand's Agenda for Children: Making Life Better for Children (Wellington, 2002) 11.

110 Green, above n 4, 204. See Ministry of Health, above n 49, 54; American Academy of Pediatrics (Committee on Bioethics), above n 65, 315.

111 Prince v Massachusetts (1944) 321 US 158, 170 Rutledge J, quoted in Silverman, above n 101, 281.

112 See American Academy of Pediatrics (Committee on Bioethics), above n 65, 315; O'Donnell, above n 27 , 'Parental Decision Making'; New Zealand Health Trust, above n 78, 19.

113 O'Donnell, above n 27, 'Parental Decision Making'. See Childhood Immunisation, above n 2, 13-14; Fisher 2, above n 69; Gillick v West Norfolk Health Authority [1985] 3 All ER 402, 420-421 (HL) Lord Scarman; Ministry of Social Development, above n 109, 11.

114 See Dewar, above n 108, 68; Silverman and May, above n 34, 518; Childhood Immunisation, above n 2, 14. See generally Care of Children Act 2004, s 4; Convention on the Rights of the Child, above n 33, art 3(1).

115 See for example O'Donnell, above n 27, 'Welfare and Best Interests' and 'Welfare and Medical Best Interests'.

116 See Childhood Immunisation, above n 2, 13-14; Silverman and May, above n 34, 518-519; McIntyre, Alison Williams and Leask, above n 20, 150. There is no consensus that refusal of non-lifesaving immunisation constitutes legal neglect: Childhood Immunisation, above n 2, 14. But see Dr Don Brash MP, above n 80. 
commentators, children's best interests are inextricably linked with the ability of those with primary responsibility for them to make decisions about their upbringing. ${ }^{117}$

Feudtner and Marcuse have identified a general tension between "the duties that our society entrusts to parents to promote the health and safety of their children and assigns to governmental and other agencies to safeguard the welfare of children." 118 The State decision that the best interests of children, both as a group and (almost always) individually, lie in receiving immunisation renders parental refusal of immunisation inherently problematic.

\section{Striking a balance}

If we accept that immunisation decisions should be made by reference to a child's best interests, the current legal framework is not entirely satisfactory. If parents are united in refusing immunisation, there is no way of ensuring they have not made a demonstrably wrong decision on medical grounds, or that their own broader interests have not (consciously or otherwise) dominated to the detriment of their child. ${ }^{119}$ If parents disagree, by contrast, the important benefits in having immunisation decisions made by a child's primary caregivers seem in danger of being swamped by the courts' focus on medical best interests. ${ }^{120}$

The balance between the various parties with legitimate interests in the immunisation of a child (which, beyond child, family and State, may also include doctors with professional duties of care to the child) is a sensitive one. ${ }^{121}$ However, the likelihood of a result that effectively balances parental decision-making and the best interests of the child may be enhanced by the introduction of an exemption scheme. By clearly articulating the various interests in play, legislation could raise parental awareness that immunisation decisions have implications beyond the immediate family

117 See O'Donnell, above n 27, 'Parental Decision Making'; Silverman and May, above n 34, 518; American Academy of Pediatrics (Committee on Bioethics), above n 65, 315; McIntyre, Williams and Leask, above $n$ 20, 150; Fisher 2, above n 69.

118 Feudtner and Marcuse, above n 16, 1160. See also Silverman and May, above n 34, 509 (footnote 21) and 518-519; Angus, above n 34, 147.

119 See generally O'Donnell, above n 27, 'Parental Decision Making'.

120 See O'Donnell, above n 27, 'Welfare and Medical Best Interests' and 'The Court of Appeal Judgments'. The State's general bias towards immunisation on medical grounds is demonstrated where disagreement between caregivers leads to applications to the courts and an increasingly acrimonious series of hearings; even in the face of fervent opposition from the primary caregiver, immunisation has generally been ordered to proceed. See Re C and F (children) (immunisation) [2003] All ER 179 (HC); Re C (Welfare of Child: Immunisation) [2003] EWCA Civ 1148; Rogal v Smith [2003] NZFLR 75 (FC); Dyer, above n 24; Clare Dyer "Mothers Lose Anti-MMR Battle" (31 July 2003) The Guardian <http://www.guardian.co.uk> (last 1618 April 2006); Meikle, above n 24.

121 See American Academy of Pediatrics (Committee on Bioethics), above n 65, 315; Feudtner and Marcuse, above n 16, 1159; New Zealand Health Trust, above n 78, 19. 
environment. More practically, legislation could limit parents' ability to refuse immunisation to circumstances where the State is satisfied that medical best interests have been adequately considered and that refusal is unlikely to be clearly against the overall best interests of a child. ${ }^{122}$

Given that there are valid reservations about resolving disputes over routine childhood immunisation through the courts, ${ }^{123}$ it may be that alternative dispute resolution should be facilitated by legislation introducing an exemption scheme. Mediation, for example, could be relatively accessible, keep bad feeling to a minimum and focus on persuasion rather than coercion. If the exposition of all points of view (including, potentially, a State-appointed representative of the child) failed to secure consensus, the situation could proceed to binding arbitration.

\section{THE TROUBLE WITH INFORMED DECISIONS}

\section{A The State Taking Sides}

If the State imposes an informed refusal requirement, it must ensure that the preconditions for making an informed decision are present. ${ }^{124}$ For this to happen, parents need medical information that is "objective, balanced and politics-free", ${ }^{125}$ in order to be "as fully informed as possible, within the available information and [their] own limitations". ${ }^{26}$ This can be problematic, not only because the State has to monitor the information it provides to ensure that its vested interest in immunisation does not overwhelm the decision-making process, but also because it must grapple with the (mis)information available from non-official sources.

\section{Providing information}

The Ministry of Health has not attempted to maintain a rigid distinction between its responsibilities to promote immunisation and to facilitate informed decisions. This is defensible, notwithstanding concerns that it gives rise to an irreconcilable conflict of interest, ${ }^{127}$ since official policy may be seen as reflecting an informed societal decision to accept immunisation. However, care must be taken to ensure that the Ministry's motive in providing immunisation information is, and is seen to be, the facilitation of free decisions rather than the ticking of a procedural box in pursuit of universal immunisation.

122 See Part VI B Statutory Exemptions and the Illusion of Choice.

123 See generally O'Donnell, above n 27; Dyer, above n 120.

124 Immunisation Handbook 2002, above n 4, 32-33.

125 Childhood Immunisation, above n 2, 15. See also New Zealand Health Trust, above n 78, 6.

126 The Health and Disability Commissioner, above n 103.

127 See New Zealand Health Trust, above n 78, 5-6; New Zealand Anti-Vivisection Society, above n 22. 
Face-to-face interactions between health professionals and consumers are undoubtedly the most important in terms of the facilitation of immunisation decisions, and the only time the State has an effective monopoly as against the anti-immunisation lobby. Notwithstanding fairly detailed Ministry directives, ${ }^{128}$ information given to parents during oral consultations "is at the complete discretion of the provider, who will often place their own emphasis on different aspects of the benefits, costs or otherwise of immunisation." 129 The trust generally, but not always, placed in doctors by parents requires policy-makers to tread carefully in making demands upon providers that might be unrealistic (for example, parents with "emotional rather than intellectual" objections to immunisation are unlikely to be swayed by medical argument) ${ }^{130}$ or require them to play a more aggressive role than their professional obligations would generally envisage. ${ }^{131}$

Outside the doctor's office, 90 per cent of parents in a 2003 survey felt that the Ministry's standard information was adequate to enable them to make informed immunisation decisions. ${ }^{132}$ Although this does not of course mean that the information is adequate in objective terms, it is encouraging, especially since there is actually much more Ministry-sanctioned information available. For example, the ubiquitous Well Child Handbook describes the Immunisation Advisory Centre as the "first port of call" for concerned parents. ${ }^{133}$ This Centre, Ministry-founded and based at the University of Auckland, aims to promote immunisation awareness and to "influence attitudes by the provision of knowledge" to providers and the community. ${ }^{134}$

\section{Countering misinformation}

Much is made of the dependence of parents upon immunisation information provided by health professionals. ${ }^{135}$ On the other hand, officials are becoming increasingly open about the fact that

128 See Immunisation Handbook 2002, above n 4, 33 and 240-241.

129 Green, above n 4, 206

130 Immunisation Handbook 2002, above n 4, 241. See McIntyre, Williams and Leask, above n 20, 150-151.

131 See generally Green, above n 4, 207; The Health and Disability Commissioner "Informed Choice - Not a Matter of Negotiation" (9 February 2005) <http://www.hdc.org.nz $>$ (last accessed 18 April 2006); The Immunisation Awareness Society Inc <http://www.ias.org.nz> (last accessed 18 April 2006); Childhood Immunisation, above n 2, 18-20; Diekema, above n 17.

132 A multilingual brochure and more comprehensive booklet, also available electronically: Ministry of Health "National Immunisation Programme News" (Issue 2, July 2003) <www.moh.govt.nz> (last accessed 18 April 2006).

133 Well Child, above n 33, 141

134 Progress on Health Outcome Targets 1998, above n 30, 80. See also Immunisation Advisory Centre $<$ www.immune.org.nz> (last accessed 18 April 2006).

135 Childhood Immunisation, above n 2, 18; Ann Robinson "Cracks in Public Confidence" (11 August 2004) The Guardian <http://www.guardian.co.uk> (last accessed 18 April 2006); United States Department of Health and Human Services (National Vaccine Program Office), above n 80. 
most of the mass of private immunisation information available aims to influence attitudes away from immunisation, ${ }^{136}$ and, more ominously, may not adhere to "good information practices". ${ }^{137}$ Research has revealed worrying levels of ignorance among New Zealand parents, directly fuelled by anti-immunisation material. For example, one in five believes that good hygiene and nutrition can prevent communicable diseases. ${ }^{138}$ There is little point in the State providing balanced immunisation information if private groups that have no such compunction succeed in triggering an "inappropriate erosion of public confidence". ${ }^{139}$

That said, it is unrealistic to imagine that immunisation misinformation could be entirely eliminated. For example, the chances of successfully silencing the plethora of mostly international anti-immunisation websites are slim indeed. More importantly, the censorship of minority opinions is both deeply constitutionally problematic and unlikely, unless conducted with brutal efficiency, to do more than increase the determination of those holding the opinions to get their message across. $^{140}$

What policy-makers can and should do is confront the arguments of the anti-immunisation lobby in an "open and unbiased" way. ${ }^{141}$ It may not be possible or desirable to counter all of these arguments on their own terms (for example, suggestions that the government's sole motivation in providing immunisation is profit), but it is possible to disabuse consumers of the notion that they have stumbled onto secret truths about immunisation that providers are unable or unwilling to see. Government-sanctioned organisations overseas have taken proactive approaches to the spectre of misinformation, for example by providing consumers with criteria against which they are encouraged to assess immunisation websites before relying upon their advice. ${ }^{142}$

136 See for example American Academy of Pediatrics (Childhood Immunization Support Programme) "Letter from American Academy of Pediatrics President, Carol Berkowitz, MD, FAAP" <www.cispimmunize.org> (last accessed 18 April 2006); United States Department of Health and Human Services (Centers for Disease Control and Prevention) "Six Common Misconceptions about Vaccination and How to Respond to Them" $<$ http://www.cdc.gov> (last accessed 18 April 2006).

137 World Health Organisation "Vaccine Safety Net" <www.who.int/immunization_safety > (last accessed 18 April 2006).

138 Ross, above n 17. See generally Diekema, above n 17, 1429.

139 Childhood Immunisation, above n 2, 8.

140 Section 14 of the New Zealand Bill of Rights Act 1990 protects the right to freedom of expression; Bradley, above $\mathrm{n} 75,331$.

141 Kempe, above n 2, 45.

142 See Childhood Immunisation, above n 2, 19; National Network for Immunization Information "Parents: Evaluating Information on the Web" <http://www.immunizationinfo.org> (last accessed 18 April 2006); Vaccine Safety Net <www.who.int/immunization_safety $>$ (last accessed 18 April 2006); Kempe, above n 2 , 45. 
Although the Ministry has taken a positive step by including a section devoted to handling commonly-raised objections to immunisation in the current handbook for providers, ${ }^{143}$ it may be necessary to accept that more forceful measures are needed. The Immunisation Advisory Centre's ability to "influence attitudes through the provision of knowledge" could be crucially valuable in this regard. ${ }^{144}$

\section{B Statutory Exemptions and the Illusion of Choice}

The concept of a legal framework designed to enforce choice is slightly counter-intuitive. In its usual context, the principle of informed consent creates a prohibition on any action unless the consumer agrees. An 'opt-out' system, by contrast, requires parents to immunise their children (which may only require sending them to school, where catch-up vaccinations can be administered) unless they positively refuse. The minimum action required of parents in overseas jurisdictions is ticking a refusal box. More onerous requirements can extend from providing written reasons, to failing to be persuaded by mandatory education sessions, to proving that refusal is based on a specific, legislatively sanctioned ground.

\section{Exemption, objection or abstention?}

The degree of stigma that would or should attach to un-immunised children and their parents under an exemption scheme would likely relate to the degree of moral pressure imposed by originating legislation. ${ }^{145}$ Certainly, whether legally 'opting out' is presented as a right or an unfortunate necessity, there should be a disincentive for refusal that does not follow these processes. Unfortunately, conceptualising an appropriate sanction for failure to make a legally supervised choice is no easier than doing so for defiance of a mandatory immunisation law. ${ }^{146}$

\section{Taking the easy way out}

Although it must not be prohibitively difficult to opt out of immunisation, it must not be too easy either. If it is seen as less onerous to get an exemption than to get a child immunised, at least some parents will claim what are known as "exemptions of convenience" and passive nonimmunisation will not be successfully eliminated. ${ }^{147}$ The free rider problem is also an ever-present one. Like other common goods, population immunity hinges on peoples' willingness to take both

143 Immunisation Handbook 2002, above n 4, ch 19. Compare United States Department of Health and Human Services (Centers for Disease Control and Prevention) "Six Common Misconceptions about Vaccination and How to Respond to Them" <http://www.cdc.gov> (last accessed 18 April 2006).

144 Progress on Health Outcome Targets 1998, above n 38, 80.

145 See generally Gary Krasner "The Philosophic Exemption" (2002) < http://www.garynull.com> (last accessed 18 April 2006).

146 See Part IV C 1 How do you enforce an immunisation law?; Part VII B 1 Sanctions and incentives.

147 Calandrillo, above n 4, 360, 412-413, 417 and 432-433; Salmon, above n 19, 3. 
individual and collective interests into account in decision-making. Even if the risk of disease becomes comparable to the risk inherent in immunisation (as, ideally, it should), ${ }^{148}$ the scales will tip back dramatically if people begin to take that risk for granted. It is imperative that, if opting out is permitted on the basis of concerns about adverse events, adequate resources are devoted to battling complacency about the threat posed by actual diseases. ${ }^{149}$

The difficulty lies in avoiding undue pressure upon the minority of parents who have deeply held objections to immunisation, while making it clear that 'opt-out' provisions are not intended to be (and, if population immunity thresholds are to be reached, must not be) relied upon by anyone else. Some commentators believe that this can be achieved through a focus on the content of informed refusal, with Salmon suggesting that an exemption law should: ${ }^{150}$

... require parents who are considering philosophical or religious exemptions for their children to attend

individual educational counselling provided by a nurse or health educator knowledgeable of vaccine

issues, outlining the individual and societal risks of not vaccinating.

To legally refuse immunisation in Australia, for example, parents must obtain a certificate stating that a registered provider has taken them through a benefit-risk analysis. ${ }^{151}$ Unfortunately, while this kind of education requirement may dissuade exemptions of convenience, it will not hamper those determined to refuse immunisation on grounds that the State considers unacceptably selfish or irrational.

\section{Drawing the line}

The United States experience is generally looked to by jurisdictions that are considering moving to an informed choice model. However, the basic premise that the substance of a decision is not to be dictated by the State has only recently become evident in United States immunisation laws. In fact, most states used to limit the possibility of opting out to medical grounds (where a child is contra-indicated or has acquired natural immunity), ${ }^{152}$ which effectively amounted to mandatory immunisation. It was from this starting point that states were driven, as individual freedom began to assume greater prominence, to draft increasingly permissive, non-medical grounds for opting out. ${ }^{153}$ As a result, countries like Australia, which have graduated from voluntary immunisation up to

148 See Part II A 2 Risks.

149 Salmon, above n 19, 2; Calandrillo, above n 4, 359-361; Feudtner and Marcuse, above n 16, 1159-1160; Allen, above n 5, 'Mandatory Vaccination Laws'; Diekema, above n 17, 1429.

150 Salmon, above n 19, 4. See also Silverman, above n 1, 294.

151 Australian Government Family Assistance Office "Maternity Immunisation Allowance" $<$ www.familyassist.gov.au> (last accessed 18 April 2006).

152 Smith, above n 89, 251; Calandrillo, above n 4, 382-383; Hinman and others, above n 8, 124.

153 See Calandrillo, above n 4, 382-383 and 416; Smith, above n 89, 251. 
informed choice, ${ }^{154}$ have tended to adopt an essentially categorical approach which places substantive and not just procedural limits on people's ability to refuse immunisation.

The issue of which non-medical exemptions should be legally sanctioned, and what burden people should have to discharge to bring themselves within those exemptions, continues to be bitterly controversial. ${ }^{155}$ It is complicated by the fact that debates about the merits of different objections to immunisation are often conducted in the abstract, but must be subjugated to the bottom line of achieving population immunity targets if an exemption scheme is to realise its purpose.

The two dominant categories of non-medical statutory exemption are 'religious' and 'philosophical'. It is regularly assumed that religious convictions deserve special recognition, not least because their free expression is constitutionally guaranteed. ${ }^{156}$ However, religious exemptions are often claimed within close-knit denominational communities, leading to clusters of unimmunised children. ${ }^{157}$ Further, the definition of a religious objection has become increasingly fraught. ${ }^{158}$ Very few religions actually forbid immunisation. Yet many people do feel that immunisation is incompatible with their personal spiritual convictions; and whether or not those convictions are mandated by a particular religious denomination does not affect their sincerity.

So-called 'philosophical' exemptions emerged partly to cater for spiritual beliefs that are independent of an institutional religion, partly for explicitly secular disagreement with immunisation science or State-mandated health interventions. ${ }^{159}$ Although there is arguably no principled reason to permit religious but not philosophical exemptions, ${ }^{160}$ the latter can be invoked in an alarming multiplicity of situations. This is especially so given that there is not even an inbuilt (if arbitrary) burden of proof, such as having to demonstrate membership of an organised religion. ${ }^{161}$ Many United States jurisdictions will accept an affirmation of philosophical opposition to immunisation on its face, and over half have never refused an exemption request. ${ }^{162}$ Policy-makers must strike a

154 See Australian Government Family Assistance Office, above n 151.

155 See generally Calandrillo, above n 4; Salmon, above n 19; Smith, above n 89; Silverman, above n 1; Krasner, above n 145; Silverman and May, above n 34

156 Yet there is no constitutional right to a religious (or philosophical) exemption from immunisation in the United States: Hinman and others, above n 8, 126; Silverman, above n 1, 281.

157 Calandrillo, above n 4, 415; Hinman and others, above n 8, 125; Silverman, above n 1, 285; Childhood Immunisation, above n 2, 12 .

158 See Calandrillo, above n 4, 414-415; Hinman and others, above n 8, 124-125; Silverman, above n 1, 282284.

159 See generally Krasner, above n 145 .

160 See generally Krasner, above n 145.

161 See Silverman and May, above n 34, 515-516; Silverman, above n 1, 284-285.

162 Hinman and others, above n 8, 125; see Salmon, above n 19, 3. 
difficult balance between ensuring that parents have "good cause" for claiming an exemption, ${ }^{163}$ and not being seen to discriminate between parents whose opposition to immunisation is equally fervent.

\section{Summary}

Once legislation begins to dictate the form that an informed refusal must take, it is a small step to dictating the basis of that refusal. If immunisation must be refused by reference to a legislatively specified ground, the inevitable implication is that there are grounds for opposition to immunisation that will not give rise to a legal entitlement to refuse it. This can only be reconciled with the State's obligation to respect "voluntary, informed and competent" decisions if it is accepted that someone who refuses immunisation on a non-sanctioned ground is necessarily uninformed and/or incompetent. ${ }^{164}$ In reality, as soon as a categorical exemption scheme is implemented, we have moved to a form of genuinely coercive immunisation.

This arguably does not mean it must not be considered for New Zealand. At present, the State can give parents appropriate information, but can only hope that they will make their decision on the basis of that information. Implementing a bare informed refusal requirement would not substantially alter this position, except that parents could be compelled to receive information instead of just being offered it. A carefully-designed categorical approach, by contrast, might harm no one. At worst, it would benefit everyone by enabling population immunity levels to be achieved, while harming those whose 'choice' to refuse immunisation was either considered to be selfish and/or irrational, or (in the absolute worst-case scenario) less deeply motivated than the five per cent that could safely be permitted to abstain from an immunisation programme. The political risk associated with prioritising certain grounds for refusing immunisation cannot be ignored, but the government that implements an exemption scheme would have to be prepared to draw the line somewhere and, if necessary, to revise that line. ${ }^{165}$

\section{Risk Communication and Adverse Events}

If the State plays an active role in promoting immunisation as beneficial, it should also take some responsibility for anyone that immunisation actually harms. ${ }^{166}$ At present, New Zealand has a relatively comprehensive framework for both monitoring and remedying, as far as practicable, the tiny but real risk associated with immunisation. ${ }^{167}$ Although compensation levels are not

163 This is the criteria for claiming an exemption in Ohio: Krasner, above n 145, 'Postscript 1'.

164 See Part V A The Content of Informed Decisions.

165 See generally Salmon, above n 19, 3-4; Calandrillo, above n 4, 418; Hinman and others, above n 8, 127.

166 See Kempe, above n 2, 49; Calandrillo, above n 4, 408.

167 See Kempe, above n 2, 49. 
particularly generous, ${ }^{168}$ anyone who can prove they have been harmed by an immunisation event is entitled to cover under New Zealand's statutory no-fault accident compensation scheme. ${ }^{169}$

Arguments that extraordinary levels of compensation should be available for immunisationrelated harm because it is incurred in the service of the public good, as advanced in the United States, ${ }^{170}$ are not persuasive. In addition to the indirect benefits that flow from a decreased societal risk of disease, immunisation almost always benefits individual recipients, especially by comparison with the probable outcome of infection with the relevant disease; ${ }^{171}$ it cannot be characterised as a sacrifice in the way that, for example, military service can.

It is possible to imagine an unfortunate situation where an injured child's parents had consented to immunisation without full appreciation of the risks involved, whether or not those risks were unusually high for the particular child. Even if the child emerged unscathed, anger when risks had been downplayed by a provider would be understandable. Yet, any system established to address breakdowns in risk communication might be placed under pressure to cater also for those who claimed the benefits of immunisation had been insufficiently stressed, if, for example, an unimmunised child went on to contract a preventable disease. If New Zealand adopts an 'opt-out' system, the State's power to manipulate public awareness of the benefits and risks of immunisation (and thereby actual coverage rates) will be accurately perceived as having grown; and the likelihood that people will want to blame the State for decisions that turn out to be the wrong ones may grow correspondingly.

Although it is possible to develop internal processes to address the problem of provider information failures, a more transparent accountability process could be a valuable tool in the struggle to maintain public confidence in an immunisation programme. On the other hand, lynching of individual providers would be unlikely either to improve their performance or their credit rating with the public, and litigation against the State would probably sour more relationships than it would mend.

It is submitted that policy-makers should give consideration, first, to emphasising that most fully informed people decide to immunise their children and therefore there is no need to manipulate the decision-making process to achieve immunisation targets; and secondly, to effectively publicising an individual avenue of complaint that will vindicate the right to informed consent/refusal without

168 See generally William J Gaine "No-Fault Compensation Systems" (2003) 326 BMJ 997. Compare Calandrillo, above n 4, 408; United States Department of Health and Human Services (Health Resources and Services Administration) "Commonly Asked Questions about The National Vaccine Injury Compensation Program" <http://www.hrsa.gov> (last accessed 18 April 2006).

169 See Injury Prevention, Rehabilitation and Compensation Act 2001, ss 32-34.

170 See for example Fisher 1, above n 22.

171 See Part II A 2 Risks. 
cultivating a culture of blame. Exposition of the options for such a forum is beyond the scope of this article, but a starting point could be the ability of the Health and Disability Commissioner to receive and investigate complaints about breaches of the informed consent provisions in the Code. ${ }^{172}$

\section{IMMUNISATION AND BENEFICIARIES}

So far, this article has assumed that any reform that aimed to lift our immunisation coverage levels would do so by imposing identical obligations on all New Zealand parents. ${ }^{173}$ However, in the 2005 election year, the National Party of New Zealand (National) revived a proposal of the 1990s that the strengthening of legal obligations in respect of immunisation should be, at least for now, confined to one section of the population. It is suggested that the receipt of certain social security benefits could legitimately be conditioned upon the immunisation status of beneficiaries' children. ${ }^{174}$

This section argues that notwithstanding the various justifications advanced for implementing a targeted immunisation law, and the existence of some overseas precedents, capitalising upon the embedded vulnerability of beneficiaries is not defensible in principle and should certainly not be prioritised over other available policy options.

\section{A Why Single Out Beneficiaries?}

\section{Discrimination?}

There is a presumption in New Zealand that it is not generally legitimate to impose more onerous obligations upon beneficiaries because they are beneficiaries. ${ }^{175}$ An immunisation law that applied only to beneficiaries could, in general terms, be seen to discriminate against them. However, more precisely, a targeted law would create a distinction between would-be beneficiaries, in that only parents of children whose immunisation status was not legally sanctioned could be penalised. It is unlikely that immunisation status per se could be considered a prohibited ground of

172 See for example The Health and Disability Commissioner "Informed Consent for Child Receiving Vaccines" (Case Note, 18 September 2002) <www.hdc.org.nz> (last accessed 18 April 2006).

173 As has the Ministry of Health in its recent discussion papers: see Part III B 3 Public health reform.

174 See Dr Don Brash MP "Welfare Dependency: Whatever Happened to Personal Responsibility?" (Speech to Orewa Rotary Club, Orewa, 25 January 2005) 11 [Orewa Speech]; Welfare Dependency Discussion Paper, above $\mathrm{n} 19,14-15$. For the historical context of the 2005 proposal, see Department of Social Welfare, above n $87,45-48$.

175 Both the generally-phrased section 19 of the New Zealand Bill of Rights Act 1990 and the specific provisions in Part 2 of the Human Rights Act 1993 (HRA) affirm the right of New Zealanders to be free from discrimination upon certain prohibited grounds. Section 21(1)(k)(ii) of the HRA provides that employment status, including being a recipient of a benefit, is one of these grounds. See Child Poverty Action Group Inc "HRC Complaint D1951: Child Poverty Action Group / Child Tax Credit" $<$ http://www.cpag.org.nz $>$ (last accessed 18 April 2006) 2. 
discrimination. The right to refuse medical treatment could be invoked to support an indirect argument that people who choose to exercise it by refusing immunisation cannot legitimately be discriminated against, but only if it was first accepted that the limits placed upon individual autonomy by immunisation laws are incapable of being "demonstrably justified". ${ }^{176}$

\section{The visible target}

The question of how immunisation laws can be successfully enforced has continued to trouble policy-makers. ${ }^{177}$ Instinctive confusion about why an immunisation law should be restricted in its scope to one section of the population is arguably answerable by the plain fact that the State has more economic and political control over beneficiaries than non-beneficiaries. Financial penalties for non-compliance with immunisation requirements, in particular, are likely to encounter less resistance if the money being extracted or withheld is seen by the non-beneficiary majority to be the legitimate property of the State in the first place.

If a targeted law was to secure population immunity as currently defined, the number of children whose immunisation it would secure plus the number of currently immunised children would have to equal at least 95 per cent of the population. ${ }^{178}$ Whether or not there are enough un-immunised children of beneficiaries to make this equation work, National has not actually proposed a mandatory immunisation requirement - as might be contemplated, for example, for an extreme religious sect unanimously opposed to immunisation. Instead, it is suggested that beneficiaries should be forced by an 'opt-out' law to make an informed decision about immunisation, ${ }^{179}$ meaning that the law could guarantee only the addition of passively non-immunised children of beneficiaries to our immunisation statistics. Given that passive non-immunisation is not a phenomenon solely limited to beneficiaries, this could not single-handedly close our immunisation gaps.

That said, National's proposal could be seen as an important step in the right direction, ${ }^{180}$ in that there is considerable evidence to suggest that children of beneficiaries are more likely to be passively un-immunised and are disproportionately at risk of contracting vaccine-preventable diseases. ${ }^{181}$ Notwithstanding that it would probably be more accurate to describe our immunisation

176 See New Zealand Bill of Rights Act 1990, ss 5 and 11.

177 See Part IV C 1 How do you enforce an immunisation law?

178 See Part II A 1 Population immunity.

179 National Party of New Zealand "Bad Day Steve?" (13 March 2003) Media Release; Orewa Speech, above n $174,11$.

180 See Welfare Dependency Discussion Paper, above n 19, 15.

181 National Health Committee Review, above n 10,1 and 7; Immunisation in New Zealand, above n 2, 2. See generally L C Kerpelman, D B Connell and W J Gunn "Effect of a Monetary Sanction on Immunization Rates of Recipients of Aid to Families with Dependent Children" (2000) 284 JAMA 53; Tim O'Donovan, 
gaps as between low and high-income than beneficiary and non-beneficiary families, ${ }^{182}$ there is a fairly sound pragmatic argument for focusing scarce resources on the immunisation of beneficiary children. However, unless and until it can be established that beneficiaries are both necessarily and exclusively accused of inertia in respect of immunisation, arguments that they present an efficient target do not provide a principled justification for a targeted law.

\section{Reciprocal obligations}

All this is not to say that no principled justification has been advanced for limiting coercive initiatives to beneficiaries. Mead's assertion that the world beneficiaries inhabit "is economically depressed yet privileged in one sense, in that it emphasizes their claims and needs almost to the exclusion of obligations", ${ }^{183}$ underpins National's avowal that there is a choice to be made by beneficiaries entering a "contract" with the State: ${ }^{184}$ between accepting both State support and "an expectation that certain things will be done in return", ${ }^{185}$ or ceasing to enjoy that support. ${ }^{186}$ In the immunisation context, this translates into an argument that beneficiaries have no right to expect the State to help them bring up their children if they do not seriously consider having those children immunised. ${ }^{187}$

\section{B Immunisation as a Reciprocal Obligation}

Two potentially conflicting messages underpin National's proposal. On one hand, there is Dr Don Brash MP's insistence that all parents have obligations to ensure that children are immunised and that "it is about time New Zealanders made it clear that this form of child neglect is

Karen McMillan and Heather Worth "An Employment Barrier: The Health Status of DPB Recipients' Children" (2004) 22 SPJNZ 97.

182 See National Health Committee Review, above n 10, 1 and 7; Immunisation in New Zealand, above n 2, 2. This assertion may be refined, or disproven, by the successful implementation of the National Immunisation Register.

183 Mead, above n 80, 2.

184 Judith A Davey (ed) Another New Zealand Experiment: A Code of Social and Family Responsibility (Institute of Policy Studies, Wellington, 2000) 32. See Ruth Smithies "Beyond Belief: The Social Responsibility Dimension" (Speech to Sea of Faith Conference, Havelock North, 6-8 October 2000) 'The Draft Code of Social and Family Responsibility'.

185 This is described by Katherine Rich MP as a key component of National's ideal welfare system: Welfare Dependency Discussion Paper, above n 19, 13.

186 See Jonathan Boston "Morals, Codes and the State: Reflections on 'Another New Zealand Experiment"" in Davey, above n 184, 168, 179. See further Robert Stephens "Social Policy and Benefit Reform" (Paper presented to IIR Seminar on Successful Government Policy: Designing, Implementing and Evaluating, Wellington, 24 October 2001) 14.

187 Dr Don Brash MP, above n 80. See generally Boston, above n 63, 36. 
unacceptable". ${ }^{188}$ To justify a targeted law on this basis, we must define 'New Zealanders' not as parents (from all walks of life) who do immunise their children, but as non-beneficiary parents (who may or may not do so).

On the other hand, it seems that it is the process of making a choice, rather than the immunisation outcome for a particular child, which is National's primary concern. ${ }^{189}$ Rather than contributing to the diminution of "personal responsibility" by unconditionally guaranteeing financial support, ${ }^{190}$ the State has "an opportunity, if not an obligation" to work to re-instil it by ensuring that beneficiaries make active choices about their own and their family's future. ${ }^{191}$ A legal framework that either made immunisation decisions at the societal level or permitted beneficiaries to ignore immunisation altogether would be counterproductive.

\section{Sanctions and incentives}

Some commentators have found the thought of subjecting beneficiaries to behavioural conditions under threat of the withdrawal of State support morally abhorrent. Claiming that beneficiaries are "sufficiently obligated by poverty", ${ }^{192}$ it is suggested that "the necessities of human life and dignity" 193 must be realised for all, without stigma, ${ }^{194}$ before we can legitimately "encourage all citizens to fulfil their potential and contribute to the common good". ${ }^{195}$

Yet it is the likelihood of further disadvantaging children who are already disproportionately at risk of disease that is, arguably, most concerning. It is not generally thought that New Zealand's benefit rates are so high that they can be safely trimmed. ${ }^{196}$ On the contrary, Stephens warned in 2003 that "[u]ntil there are increases in the level of generosity to families with dependent children in New Zealand, adverse outcomes for children are lively to bedevil the country for years to come."197

188 Dr Don Brash MP, above n 80.

189 See Welfare Dependency Discussion Paper, above n 19, 15.

190 See generally Orewa Speech, above n 19.

191 Welfare Dependency Discussion Paper, above n 174, 13.

192 Mead, above n 80, 201.

193 Methodist Mission (South Island), above n 93.

194 Ramesh Mishra (ed) Society and Social Policy: Theories and Practice of Welfare (2 ed, Macmillan, London, 1981) 24

195 Methodist Mission (South Island), above $\mathrm{n} 93$.

196 See Robert Stephens "Poverty, Family Finances and Social Security" in Boston, Dalziel and St John (eds), above n 63, 238, 256.

197 Robert Stephens "The Level of Financial Assistance to Families with Dependent Children: A Comparative Analysis" (2003) 20 SPJNZ 173, 194 (emphasis added). See further Ministry of Social Development, above n 109, 24. 
Regarding immunisation as an opportunity to hone the decision-making capabilities of beneficiary parents carries with it an acceptance that those who fail to make a choice should bear 'responsibility' for the consequences of their actions. However, the way in which this is logically done is through reducing the level of financial support available to parents; and whatever this does to parents, it will almost certainly have the flow-on effect of punishing their children. ${ }^{198}$

To avoid the appearance of making "poor families poorer", ${ }^{199}$ the enforcement of targeted immunisation laws can be couched in terms of 'incentives' rather than 'sanctions'. An incentive could be conceptualised as an expression of gratitude for participation in a civic endeavour, and would aim to attract those in the grip of parental inertia while avoiding pressure on parents actively opposed to immunisation. The recently implemented Australian Maternity Immunisation Allowance, a one-off payment for children under two years of age, is an example offering an independent complement to the main source of family assistance. ${ }^{200}$ However, unlike the subsidiary child-care benefit, which may be denied for non-compliance with immunisation requirements and therefore operates as a sanction, the Allowance is available to beneficiaries and non-beneficiaries alike. ${ }^{201}$

There is no sound reason for limiting an immunisation incentive to beneficiaries, unless it is assumed that only beneficiaries will be swayed by an offer of money. Underlying this would have to be an assumption either that beneficiaries are not capable of registering the excellent non-financial reasons for participating in immunisation, or that their straitened financial circumstances do not permit them to object to being effectively bribed. If the latter, then using the terminology of incentives is not so much a concession that beneficiaries should not be denied an adequate standard of living, as an acceptance that it is permissible to maintain benefits at rates where beneficiaries will find it difficult to refuse even money that comes with strings attached.

\section{The nexus between parenting and immunisation}

Although National's proposal is that all beneficiaries with dependent children would be subject to an informed choice requirement, ${ }^{202}$ it is the Domestic Purposes Benefit (DPB) that bears the weight of attempts at justification: ${ }^{203}$

198 Compare Part IV C Practical Considerations. But see Orewa Speech, above n 174, 8: "Nobody, and certainly not the National Party, wants to make children suffer for the mistakes of their parents".

199 Rt Hon Helen Clark MP (27 April 1993) 534 NZPD 14859 (Question for Oral Answer).

200 Australian Government Family Assistance Office, above n 151.

201 Australian Government Family Assistance Office, above n 151; Australian Government Centrelink "How Much Maternity Immunisation Allowance Do I Get?" <www.centrelink.gov.au> (last accessed 18 April 2006).

202 Orewa Speech, above n 174, 11.

203 Orewa Speech, above n 174, 11. 
[T]o make it clear that the DPB is being provided primarily as a way of helping and nurturing children, and to recognize the mutual obligation involved in welfare, it will be a requirement that those receiving the DPB present their pre-school children for all appropriate vaccinations (unless they have a conscientious objection ...) .... .

There are several difficulties with this. First, any implication that the relationship between child, parent and the State can be conceptualised as an employment one (whereby the State can impose any conditions it feels would produce a better product) is dangerous. As discussed above, it is generally accepted that the care of children is a quintessentially private activity, and that parental autonomy from State interference is usually in the interests of children. ${ }^{204}$

Secondly, the explicit focus on the DPB's purpose (to enable parents to do the 'job' of parenting) exposes the artificiality in enforcing the responsibilities of parenthood through the welfare system. It seems to imply that other benefits (such as the Sickness Benefit) are not provided as a way of helping and nurturing children, which begs the question of why the State can attach conditions to do with parenting to them. It would be interesting to see if the parenting justification would change if separate benefit categories were collapsed, as the Labour government has proposed, into a universal single benefit. ${ }^{205}$ Would it be suggested that all benefits can be conceptualised as payments for rendering the service of responsible parenting? If so, could the same argument not be made, for example, in the case of tax relief for "hardworking New Zealanders" with dependent children? ${ }^{206}$

Finally, justifying an immunisation requirement by reference to the positive obligations of parenthood is problematic in that once the State begins enumerating these obligations (beyond the accepted baseline of providing the necessaries of life), ${ }^{207}$ it is difficult to know where to stop. Immunisation cannot simply be equated with good parenting: ${ }^{208}$

If the Ministry of Health wants to ... see who is doing their bit to prevent ill health, perhaps they should establish a register that lists those who eat five plus servings of fresh fruit and vegetables per day, or ... parents who ensure that their children get sufficient sleep each day.

Arguably, the greatest irony of targeted immunisation laws is that they have the effect of compromising the individual freedom of beneficiary parents (which may be a deliberate quid pro quo for their financial dependence), while prioritising the health of their children over nonbeneficiary children who are permitted to remain passively un-immunised. How can National deny

204 See Part II C 3 Children and Part V B 2 The 'right' of parents to make immunisation decisions.

205 See Hon Steve Maharey MP, Minister for Social Development and Employment "Simplified Benefit System Roll-Out Begins in May" (22 February 2005) Media Release.

206 See Dr Don Brash MP "Getting Ahead with National" (22 August 2005) Media Release.

207 See Crimes Act 1961, s 152.

208 New Zealand Health Trust, above n 78, 17. 
that their proposal would disadvantage the children of hardworking parents? Only through claiming that passive non-immunisation is not a concern for non-beneficiary children. Why? Because their parents are, fundamentally, better at their 'job'. Despite National's insistence that "many beneficiaries are great parents", ${ }^{209}$ it is difficult to shake the impression that their targeted behavioural policies rest upon a dim view of the personal qualities of welfare recipients. ${ }^{210}$

\section{To Obligate as Others are Obligated}

National's claim that conditioning benefit receipt upon immunisation would be giving effect to societal expectations about parenting is demonstrably flawed. In particular, the argument that "it is a parent's choice whether to vaccinate or not, but that it is every parent's obligation to make a choice", ${ }^{211}$ is not borne out by National's policy. Even assuming society does place this obligation on every parent, the implication is that every parent is not, should not and possibly could not be obligated to the point of compulsion. ${ }^{212}$

Mead, whose articulation of "civic conservatism" shares much at the abstract level with National's perspective on welfare, ${ }^{213}$ would regard this implication as antithetical to the supposed aim of 'reciprocal obligation', which is to eliminate the "passivity" that inhibits beneficiaries from functioning as full members of a free society. ${ }^{214}$ In Mead's view, to "obligate the dependent as others are obligated is essential to [the social goal of] equality, not opposed to it."215 A targeted immunisation law would require beneficiaries not only to be good parents, whatever that may mean, but to be better parents than non-beneficiaries, who remain free to refuse or ignore immunisation.

If immunisation is, like ensuring that children eat their vegetables, not considered important enough to constitute a prerequisite to responsible citizenship, legislation that infringes upon the personal freedom of beneficiaries in the guise of enforcing societal expectations cannot be justified. If, on the other hand, immunisation, like school attendance, is considered to be that important, then it remains impossible to defend legislation that effectively applies one standard of responsible citizenship to beneficiaries and another to non-beneficiaries.

209 Orewa Speech, above n 174, 4.

210 See generally Sue Bradford MP (Green Party Social Development Spokesperson) "Brash and Maharey in Bidding War over Beneficiaries" (4 February 2005) Media Release; Davey, above n 184, 82-83; Russell Brown "20 $0^{\text {th }}$ February 1998" < http://nznews.net.nz/hardnews> (last accessed 18 April 2006) Weblog.

211 Welfare Dependency Discussion Paper, above n 19, 15.

212 See Brown, above n 210.

213 See Mead, above n 80, 250.

214 Mead, above n 80, 220 (emphasis removed from original).

215 Mead, above n 80, 12 (emphasis added). 


\section{CONCLUSION}

As this article has demonstrated, immunisation policy does "contemplate numerous complex, contentious, and controversial themes". ${ }^{216}$ The inherent difficulties in reconciling immunisation as an individual medical intervention with immunisation as a global public health initiative cannot be overstated. For example, the fact that immunisation involves a measurable element of individual risk must be set against the interest of everyone in the suppression and (potential) eradication of communicable disease. The need to ensure that health consumers have the maximum possible latitude in decision-making must be balanced against the spectres of inertia and misinformation. And, of course, our collective responsibility to safeguard New Zealand children must be squared with the high value we place upon cohesive and self-sustaining families.

New Zealand's current coverage rates do not reflect broad national and international consensus about the great value of childhood immunisation. In abstract terms, this represents a failure to translate policy into reality; more concretely, it means that preventable diseases continue to cause needless suffering and death. To date, the law has played a comparatively muted role in the delivery of our National Immunisation Programme. There seems no reason why this should continue, given that immunisation laws have successfully boosted coverage rates in many other Western countries. However, to be both stable and effective, any proposal for immunisation law reform must grapple with the delicate balance between individual freedom and the public good.

Of the three options for reform considered in this article, two are arguably unworkable because they require, or will be perceived to require, unacceptable encroachment upon the freedom of some or all individuals. The first option involves making the essentially utilitarian decision that the benefits associated with population immunity take precedence over the harm associated with overriding opposition to immunisation, and implementing this decision by means of a universal immunisation requirement. Although there are sound arguments for conceptualising vaccinations as a public duty of all who can receive them, the idea of forcing parents to submit their children to immunisation has always been sharply divisive. In the absence of either a significant shift in public perceptions or brutal enforcement provisions, it is not a realistic option for New Zealand.

The second option involves taking advantage of the embedded vulnerability of one section of the population, by enacting targeted laws that place benefit recipients under more onerous obligations with respect to immunisation than other parents. This has little appeal in either principle or practice. On its own, a targeted initiative would be unlikely to close our immunisation gaps. Further, even if the basic premise of the 'reciprocal obligation' of beneficiaries is accepted, it is difficult to construct immunisation as an obligation of responsible citizenship without concluding that the State should be prepared to enforce that obligation for all New Zealand parents.

216 Silverman, above n 1, 278. 
While the prioritisation of individual choice in respect of immunisation may eventually prove an insurmountable obstacle to lifting us over the population immunity threshold, the basic thesis of this article is that allowing individuals to make immunisation decisions is both desirable and probably necessary to ensure continued support for the National Immunisation Programme. How can our law be strengthened without sacrificing this commitment? Through a focus, it is suggested, upon those parents who are not implacably opposed to immunisation but who nonetheless have not granted the consent currently required to secure the immunisation of their children. The fundamental difficulty with New Zealand's current 'opt-in' system is that parents are free to refuse immunisation on the basis of sketchy or no information, or to ignore it altogether. Creating a legal presumption in favour of immunisation at the point of school-entry would recast the role of parents in terms of a right to make an informed decision to opt out of, rather than in to, the national programme. Parents would not be permitted to make that decision without at least some understanding of the importance that New Zealand as a society places upon population immunity.

In theory, if the individual decision-making process was perfected, it seems that New Zealand's immunisation targets could be achieved. Therefore, an 'opt out' scheme could achieve the desired social policy end without the oppressive implications of a universal, mandatory law. If, however, the number choosing to abstain from immunisation passed the five per cent threshold, fresh consideration would need to be given to, first, whether the State's commitment to immunisation continued to reflect informed public opinion, and, secondly, whether the ongoing expenditure of effort to protect the interests of a few at the expense of all was sustainable. 